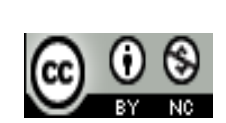

Jurnal Pendidikan Bahasa dan Sastra Indonesia is licensed under

A Creative Commons Attribution-Non Commercial 4.0 International License

\title{
Peningkatan Keterampilan Membaca Ekstensif Menggunakan Model Pembelajaran Reciprocal Teaching pada Siswa Kelas VIII D MTs Negeri Singkawang Tahun Ajaran 2016/2017
}

\author{
Yunita $^{1)}$, Fitri $^{2)}$, Zulfahita $^{3)}$ \\ 1. Program Studi Pendidikan Bahasa dan Sastra Indonesia, STKIP Singkawang, \\ E-mail: yunita@gmail.com \\ 2. Program Studi Pendidikan Bahasa dan Sastra Indonesia, STKIP Singkawang, \\ E-mail: fitri_djayadi@yahoo.co.id \\ 3. Program Studi Pendidikan Bahasa dan Sastra Indonesia, STKIP Singkawang, \\ E-mail: zulfahita@yahoo.com
}

\begin{abstract}
Abstrak. Penelitian ini dilatar belakangi oleh rendahnya nilai membaca siswa. Hal ini terjadi karena minat belajar siswa yang masih rendah dalam pembelajaran membaca dan siswa kesulitan dalam memahami materi dikarenakan guru masih kurang terampil dalam memilih model pembelajaran. Penelitian ini difokuskan pada materi membaca ekstensif menggunakan model pembelajaran reciprocal teaching. Rumusan masalah penelitian ini adalah bagaimanakah perencanaan, pelaksanaan, dan hasil membaca ekstensif menggunakan model pembelajaran reciprocal teaching. Tujuan penelitian ini adalah mendeskripsikan perencanaan, pelaksanaan, dan hasil membaca ekstensif. Metode penelitian yang digunakan adalah deskriptif dengan bentuk penelitian kualitatif. Rancangan penelitian berupa penelitian tindakan kelas. Penelitian ini terdiri 4 tahapan yaitu, perencanaan, tindakan, pengamatan, dan refleksi. Perencanaan pada setiap siklusnya mengalami peningkatan yang cukup baik yaitu siklus I $60,93 \%$ dan siklus II $78,12 \%$. Sama halnya pelaksanaan pembelajaran pada setiap siklusnya mengalami peningkatan yang cukup baik yaitu siklus I 68,75\% dan siklus II 85,71\%. Berdasarkan analisis data pada tindakan kelas ini sebelum ada tindakan nilai rata-rata $46,42 \%$ setelah tindakan siklus I adanya peningkatan menjadi $57,14 \%$ dan pada siklus II menjadi $76,03 \%$. Peningkatan yang terjadi antar kedua siklus tersebut sebanyak 9,5\%. Berdasarkan penelitian ini guru diharapkan dapat menerapkan model pembelajaran reciprocal teaching untuk meningkatkan keterampilan membaca ekstensif.
\end{abstract}

Kata Kunci : Membaca ekstensif, reciprocal teaching

\section{PENDAHULUAN}

Bahasa merupakan alat komunikasi penting yang digunakan manusia. Pembelajaran bahasa khususnya bahasa Indonesia dengan tujuan agar terampil berbahasa dan mampu berkomunikasi dengan baik dan benar. Keterampilan berbahasa mencakup keterampilan menyimak, keterampilan berbicara, keterampilan membaca, dan keterampilan menulis (Tarigan, 2008). Keterampilan membaca merupakan keterampilan ketiga yang diperoleh siswa jadi siswa harus terlibat langsung dalam kegiatan membaca. Keterampilan membaca sangat penting bagi pendidikan karena dengan membaca dapat memperoleh ilmu pengetahuan, memperoleh informasi serta dapat memperbanyak perbendaharaan kata, ungkapan dan istilah.

Berdasarkan Kurikulum Tingkat Satuan Pendidikan (KTSP) tugas seorang guru yaitu membelajarkan siswa, bukan mengajar. Pada kurikulum ini siswa didorong aktif dalam penggunaan bahasa pada pembelajaran membaca. Tugas guru, yaitu menciptakan situasi dan kondisi agar siswa belajar dengan optimal untuk melatih bagaimana siswa menggunakan bahasa agar tepat pada sasaran atau sesuai dengan dimaksud. Guru dapat menciptakan situasi dan kondisi dalam pembelajaran dengan memanfaatkan atau menciptakan model pembelajaran agar membuat siswa menjadi aktif.

Kurikulum Tingkat Satuan Pendidikan silabus mata pelajaran bahasa Indonesia Sekolah Menengah Pertama, terdapat empat keterampilan berbahasa yang sangat penting dalam kehidupan sehari-hari. Keempat keterampilan tersebut sangat terkait antara satu dengan yang lain. Menyimak dan membaca sama-sama merupakan keterampilan berbahasa yang bersifat reseptif sedangkan berbicara dan menulis merupakan keterampilan berbahasa yang bersifat produktif. Satu di antara aspek berbahasa yang diajarkan di sekolah adalah keterampilan membaca. 
Pembelajaran membaca diberikan dengan maksud agar peserta didik dapat memahami suatu bacaan dengan memperoleh informasi dan ilmu pengetahuan. Dalam hal ini, keterampilan membaca merupakan suatu kompetensi berbahasa yang harus dimiliki oleh setiap siswa selain keterampilan menyimak, berbicara, dan menulis karena pusat belajar adalah membaca. Informasi mengenai berbagai mata pelajaran yang diketahuhi dan dikuasai siswa dapat diperoleh melalui kegiatan membaca. Siswa harus memiliki kesadaran diri akan pentingnya membaca.

Membaca merupakan suatu kegiatan atau proses kognitif yang berupaya untuk menemukan berbagai informasiyang terdapat dalam tulisan (Dalman, 2013). Hal ini berarti membaca merupakan proses berfikir untuk memahami isi teks yang dibaca. Oleh sebab itu, membaca bukan hanya sekedar melihat kumpulan huruf yang telah membentuk kata, kelompok kata kalimat, paragaf, dan menginterpretasikan lambang/tanda/tulisan yang bermakna sehingga pesan yang disampaikan penulis dapat diterima oleh pembaca.

Rendahnya hasil keterampilan membaca dipengaruhi oleh beberapa faktor yaitu, minat dan motivasi siswa kurang dalam mengikuti proses pembelajaran membaca,masih banyak siswa yang belum mencapai nilai kriteria ketuntasan minimal (KKM) yaitu 70, guru masih kurang terampil dalam memilih model pembelajaran yang sesuai dengan materi membaca ekstensif, sehingga siswa sulit memahami materi, siswa kurang memperhatikan guru saat proses pembelajaran, dan siswa berasumsi bahwa membaca adalah kegiatan yang membosankan, melelahkan, dan banyak menyita waktu.

Berdasarkan identifikasi masalah tersebut maka masalah umum dalam penelitian ini adalah "Bagaimanakah Peningkatan Keterampilan Membaca Ekstensif Menggunakan Model Pembelajaran Reciprocal Teaching Pada Siswa Kelas VIII D MTs Negeri Singkawang Tahun Ajaran 2016/2017. Adapun sub-sub masalah yang akan dirumuskan dalam penelitian ini adalah (1) Bagaimanakah perencanaan pembelajaran keterampilan membaca ekstensif menggunakan model pembelajaran reciprocal teaching pada siswa kelas VIII D MTs Negeri Singkawang tahun ajaran 2016/2017? (2) Bagaimanakah pelaksanaan pembelajaran keterampilan membaca ekstensif menggunakan model pembelajaran reciprocal teaching pada siswa kelas VIII D MTs Negeri Singkawang tahun ajaran 2016/2017? (3) Bagaimanakah hasil pembelajaran keterampilan membaca ekstensif menggunakan model pembelajaran reciprocal teaching pada siswa kelas VIII D MTs Negeri Singkawang tahun ajaran 2016/2017? Adapun tujuan penelitian ini adalah (1) Pendeskripsikan perencanaan pembelajaran keterampilan membaca ekstensif menggunakan model pembelajaran reciprocal teaching pada siswa kelas VIII D MTs Negeri Singkawang tahun ajaran 2016/2017. (2) Pendeskripsikan pelaksanaan pembelajaran keterampilan membaca ekstensif menggunakan model pembelajaran reciprocal teaching pada siswa kelas VIII D MTs Negeri Singkawang tahun ajaran 2016/2017. (3) Pendeskripsikan hasil pembelajaran keterampilan membaca ekstensif menggunakan model pembelajaran reciprocal teaching pada siswa kelas VIII D MTs Negeri Singkawang tahun ajaran 2016/2017.
Berdasarkan permasalahan yang telah dipaparkan di atas, peneliti berupaya ingin mengatasi permasalahan tersebut. Peneliti menetapkan alternatif tindakan dengan menerapkan model pembelajaran reciprocal teaching untuk meningkatkan kemampuan membaca ekstensif pada siswa kelas VIII D. Pemilihan kelas VIII D didasarkan atas rendahnya hasil belajar membaca ekstensif siswa.

Membaca merupakan suatu proses yang dilakukan serta dipergunakan oleh pembaca untuk memperoleh pesan, yang hendak disampaikan oleh penulis melalui media katakata/bahasa tulis (Tarigan, 2008). Sementara pendapat lain menjelaskan bahwa "Membaca merupakan aktivitas mental memahami apa yang dituturkan pihak lain melalui sarana tulisan (Nurgiyantoro, 2010). Sedangkan naskah Slamet (2012) menyatakan "Membaca merupakan pengungkapan dan pemahaman ide, aktivitas pembaca yang diiringi curahan jiwa dalam menghayati naskah". Berdasarkan pendapat di atas dapat disimpulkan pengertian membaca adalah suatu kegiatan yang dilakukan untuk memperoleh informasi atau pesan yang hendak disampaikan penulis melalui media tulis.

Membaca ekstensif bearti membaca secara luas. Objeknya meliputi sebanyak mungkin teks dalam waktu yang sesingkat mungkin. Pengertian atau pemahaman yang bertaraf relatif rendah sudah memindai untuk ini, karena memang begitulah tuntutannya dan juga bahan bacaan itu sendiri memang sudah banyak serta berlebih-lebihan, seperti halnya dengan laporan-laporan, surat kabar. Kegiatan membaca ekstensif adalah untuk memahami isi yang penting-penting dengan cepat dengan demikian membaca secara efisien dapat terlaksana (Tarigan, 2008). Sedangkan Dalman (2013) menjelaskan "Membaca ekstensif adalah membaca secara luas. Objeknya meliputi sebanyak mungkin teks dalam waktu yang sesingkat mungkin". Berdasarkan pendapat di atas dapat ditarik kesimpulan membaca ekstensif adalah membaca secara luas suatu teks dalam waktu yang sesingkat mungkin untuk memahami isi dalam suatu bacaan.

Berita adalah setiap berita berisi pesan tertentu. Pesan itu disajikan dalam media bahasa itu berbentuk wacana, yakni wacana lisan (Slamet, 2012). Dalman (2013) "Berita adalah laporan yang benar dan pada waktunya tentang suatu peristiwa yang terjadi dalam masyarakat, tentang suatu pendapat atau pikiran baru, atau tentang apa saja yang merupakan fakta dan yang menarik serta perlu bagi pembaca umumnya. Berdasarkan pendapat diatas dapat ditarik kesimpulan bahwa berita adalah suatu informasi yang bersifat nyata dan terkini tentang suatu peristiwa yang terjadi dalam masyarakat.

Model pembelajaran reciprocal teaching merupakan pengajaran terbalik dimana guru mengajarkan siswa keterampilan kognitif penting dengan menciptakan pengalaman belajar, melalui pemodelan prilaku tertentu dan kemudian membantu siswa mengembangkan keterampilan tersebut atas usaha mereka sendiri dengan pemberian semangat, dukungan dan suatu sistem scaffolding (Tritanto, 2014). Sedangkan Pendapat lain menjelaskan bahwa "Reciprocal teaching adalah model pembelajaran yang berupa kegiatan mengajarkan materi kepada teman (Shoimin, 2016). Pada pembelajaran ini siswa berperan sebagai "guru" untuk menyampaikan materi kepada teman-temannya. Sementara 
itu, guru lebih berperan sebagai model yang menjadi fasilitator dan pembimbing yang melakukan scaffolding". Berdasarkan pendapat para ahli dapat disimpulkan bahwa reciprocal teaching adalah suatu model pembelajaran di mana siswa diberiakan terlebih dahulu suatu materi pembelajaran untuk dipelajari, kemudian siswa diminta untuk menerapkan empat strategi yaitu perangkuman, pengajuan pertanyaan, pengklarifikasian, dan prediksi dan siswa diminta untuk menyampaikan kembali materi tersebut sementara guru hanya sebagai fasilitator.

\section{METODE}

Penelitian ini dilakukan di MTs Negeri Singkawang, di Jalan Ratu Sepudak, Kelurahan Naram, Kecematan Singkawang Utara. Penelitian ini menggunakan metode penelitian deskriptif. Metode deskriptif adalah berupa katakata, gambar, dan bukan angka-angka (Moleong, 2014).

Bentuk penelitian yang digunakan dalam penelitian ini adalah bentuk penelitian kualitatif. Penelitian kualitatif adalah penelitian yang berdasarkan pada filsafat postpositivisme, digunakan untuk meneliti pada objek yang alamiah, (sebagai lawannya adalah eksprimen) dimana peneliti adalah sebagai instrumen kunci, pengambilan sampel sumber data dilakuakan secara purposive dan snowbaal, teknik pengumpulan dengan trianggulasi (gabungan), analisis data bersifat induktif/kualitatif, dan hasil penelitian kualitatif lebih menekankan makna dari pada generalisasi (Sugiono, 2016).

Rancangan penelitian ini menggunakan penelitian tindakan kelas. Arikunto (2015) menyatakan "Penelitian tindakan kelas merupakan suatu pencermatan terhadap kegiatan yang sengaja dimunculkan dan terjadi dalam sebuah kelas.

Sumber data dalam penelitian ini diperoleh dari beberapa sumber yaitu (1) Sofhy Damayanti, S. Pd., selaku guru mata pelajaran bahasa Indonesia kelas VIII D MTs Negeri Singkawang tahun ajaran 2016/2017, (2) siswa kelas VIII D MTs Negeri Singkawang yang berjumlah 28 siswa yang terdiri dari 12 siswa laki-laki dan 16 siswa perempuan. Sementara data dalam penelitian ini adalah (1) proses pembelajaran membaca ekstensif menggunakan model pembelajaran reciprocal teaching pada siswa kelas VIII D MTs Negeri Singkawang tahun ajaran 2016/2017, (2) hasil pembelajaran membaca ekstensif menggunakan model pembelajaran reciprocal teaching pada siswa kelas VIII D MTs Negeri Singkawang tahun ajaran 2016/2017.

Teknik pengumpulan data yang digunakan peneliti dalam penelitian ini meliputi teknik observasi langsung dan teknik pengukuran (tes). Alat pengumpul data yang sesuai digunakan dengan teknik pengumpul data di atas adalah lembar observasi dan tes. Sementara teknik analisis data yang digunakan dalam penelitian ini yaitu teknik statistik komparatif dan teknik analisis kritis. Adapun data yang dianalisis dalam penelitian ini yaitu, (1) kinerja guru merencanakan pembelajaran, (2) kinerja guru selama proses pembelajaran, (3) sikap siswa selama proses pembelajaran, (4) hasil keterampilan siswa dalam membaca ekstensif pada kondisi awal, siklus 1, dan siklus 2 .

\section{HASIL DAN PEMBAHASAN}

HASIL

Perencanaan Peningkatan Keterampilan Membaca Ekstensif Menggunakan Model Pembelajaraan Reciprocal Teaching Siklus I

Pada tahap perencanaan dalam kegiatan pembelajaran membaca ekstnsif peneiti dan kolaborator saling bekerja sama untuk menyusun kegiatan proses belajar mengajar yang akan dilaksanakan pada tanggal 18-19 April 2017. Pada tahap ini peneliti dan kolaborator merencanakan kegiatan pembelajaran.

Pelaksanaan Peningkatan Keterampilan Membaca Ekstensif Menggunakan Model Pembelajaran Reciprocal Teaching Siklus I

1. Kondisi Awal

Perencanaan siklus 1 dilaksanakan dari tanggal 17April 2017 peneliti dan guru bahasa Indonesia berdiskusi mengenai rencana pelaksanaan pembelajaran yang akan dilakukan ketika proses belajar mengajar. Rencana Pelaksanaan Pembelajaran (RPP) mencakup menentukan bahan pembelajaran dan merumuskan tujuan, merencanakan pengorganisasikan materi, merencanakan langkah-langkah pembelajaran, memilih sumber dan media pembelajaran, dan merencanakan evaluasi pembelajaran.

2. Pelaksanaan Pembelajaran

Pada tahap pelaksanaan siklus 1, pertemuan pertama dilaksanakan hari Selasa, 18 April 2017 pukul 10.40 sampai 12.00 dengan alokasi waktu 2 x 40 menit. Selanjutnya pertemuan kedua dilaksanakan pada hari Rabu, 19 April 2017 pukul 12.30 sampai dengan 13.50 dengan alokasi waktu $2 \mathrm{x}$ 40 menit.

\section{Pengamatan (Observing)}

1. Pengamatan Terhadap Kemampuan Guru Merencanakan Pembelajaran (APKG 1) Siklus I

Sebagian besar aspek yang dinilai dalam perencanaan pelaksanaan pembelajaran yang dilakukan sudah mencapai kriteria cukup baik karena dari 16 aspek yang dinilai pada kemampuan guru merencanakan pembelajaran keterampilan membaca ekstensif menggunakan model pembelajaran reciprocal teaching terdapat 0 aspek kriteria sangat baik (0\%), 9 aspek kriteria baik $(56,25 \%) 5$ aspek kriteria cukup baik $(31,25 \%)$, dan 2 aspek kriteria kurang baik (12,5\%). Persentasinya 60,93\% (cukup baik).

2. Pengamatan Terhadap Kemampuan Guru Melaksanakan Pembelajaran (APKG 2) Siklus I

Sebagian besar aspek yang dinilai dalam pelaksanaan pembelajaran yang dilakukan sudah mencapai kriteria baik karena dari 28 aspek yang dinilai pada kemampuan guru melaksanakan pembelajaran keterampilan membaca ekstensif menggunakan model pembelajaran reciprocal teaching terdapat 3 aspek kriteria sangat baik (10,71\%), 17 aspek kriteria baik (60,71\%), 6 aspek kriteria cukup baik $(21,42 \%)$, dan 2 aspek kriteria kurang baik $(7,14 \%)$. Persentasinya 68,75\% (cukup baik).

3. Pengamatan Terhadap Sikap Siswa dalam Pembelajaran Membaca Ekstensif Menggunakan Model Reciprocal Teaching 
Hasil pengamatan peneliti terhadap sikap dalam pembelajaran model reciprocal teaching sebagai berikut.

a) Aspek mendengarkan penjelasan guru dengan skor 4 sebanyak 5 siswa $(17,85 \%)$, siswa dengan skor 3 sebanyak 8 siswa $(28,57 \%)$, siswa dengan skor 2 sebanyak 11 siswa $(39,28 \%)$, siswa dengan skor 1 sebanyak 4 siswa $(14,28 \%)$.

b) Aspek kerjasama skor 4 sebanyak 1 siswa $(3,57 \%)$, siswa yang mendapat skor 3 sebanyak 10 siswa $(37,71 \%)$ siswa dengan skor 2 sebanyak 15 siswa $(53,57 \%)$, siswa dengan skor 1 sebanyak 2 siswa $(7,17 \%)$.

c) Aspek tanggung jawab skor 4 sebanyak 0 siswa (0\%), siswa dengan skor 3 sebanyak 7 siswa (25\%), siswa dengan skor 2 sebanyak 19 siswa $(67,85 \%)$, siswa dengan skor 1 sebanyak 2 siswa $(7,14 \%)$.

d) Aspek disiplin skor 4 sebanyak 0 siswa (0\%), siswa dengan skor 3 sebanyak 6 siswa $(21,42 \%)$, siswa dengan skor 2 sebanyak 21 siswa $(75 \%)$, siswa dengan skor 1 sebanyak 1 siswa $(3,57 \%)$.

e) Aspek menghargai skor 4 sebanyak 2 siswa $(7,14 \%)$, siswa dengan skor 3 sebanyak 6 siswa $(21,42 \%)$, siswa dengan skor 2 sebanyak 16 siswa $(57,14 \%)$, siswa dengan skor 1 sebanyak 4 siswa $(14,28 \%)$.

\section{Hasil Pembelajaran Siswa dalam Membaca Ekstensif Menggunakan Model Reciprocal Teaching Siklus I}

Hasil keterampilan membaca ekstensif siswa menggunakan model pembelajaran reciprocal teaching pada siklus 1 sudah cukup baik dengan nilai tertinggi yaitu dengan nilai 83 dan nilai terendah yaitu 33. Nilai rata-rata kelas yang diperoleh pada siklus 1 mencapai 66,53 dan nilai persentase ketuntasan mencapai $57,14 \%$. Hal tersebut artinya belum memenuhi standar keberhasilan tindakan yang ditentukan peneliti yaitu $70 \%$. Dengan demikian, secara keseluruhan pada siklus 1 dalam mengikuti kegiatan pembelajaran keterampilan menulis paragraf persuasi menggunakan model pembelajaran problem based learning belum berhasil dan akan diperbaiki dan ditingkatkan pada siklus 2 .

\section{Refleksi (Reflecting)}

\section{Refleksi Terhadap Perencanaan}

Dalam rencana pelaksanaan pembelajaran (RPP), sebagian besar aspek yang dinilai sudah mencapai kategori cukup baik namun masih ada hal-hal yang perlu diperbaiki seperti berikut. (1) Guru harus lebih kreatif mengembangkan materi pembelajaran keterampilan membaca ekstensif (2) Guru bisa membagi waktu sesuai alokasi waktu yang telah ditentukan.

\section{Refleksi Terhadap Pelaksanaan}

Refleksi terhadap tahap pelaksanaan pembelajaran yang dilakukan oleh guru sebagian besar aspek yang dinilai sudah mencapai kategori cukup baik namum masih ada hal-hal yang harus diperbaiki sebagai berikut. (1) Pada kegiatan pembelajaran guru masih kurang menguasai kelas, sebaiknya guru harus lebih tegas dengan cara menegur siswa ketika keadaan kelas ribut serta guru harus bisa mengontrol ruang kelas menjadi kondusif. (2) Pada aspek alokasi waktu tidak sesuai dengan waktu yang telah ditentukan, seharusnya dalam menyampaikan materi sudah diprediksi berapa waktu yang telah dibutuhkan sehingga waktu yang digunakan lebih efektif.

\section{Perencanaan Pembelajaran Keterampilan Membaca Ekstensif Model Pembelajaran Reciprocal Teaching Siklus} II

Pada tahap perencanaan dalam kegiatan pembeajaran membaca ekstensif peneliti dan kolaborator saling bekerjasama untuk menyusun kegiatan proses belajar mengajar yang dilaksanakan pada tanggal 8 Mei 2017.

\section{Pelaksanaan Pembelajaran Keterampilan Membaca Ekstensif Menggunakan Model PembelajaranReciprocal Teaching Siklus II}

1. Kondisi Awal

Perencanaan siklus 2 dilaksanakan dari tanggal 8 Mei 2017 peneliti dan guru bahasa Indonesia berdiskusi mengenai rencana pelaksanaan pembelajaran yang akan dilakukan ketika proses belajar mengajar. Rencana Pelaksanaan Pembelajaran (RPP) mencakup menentukan bahan pembelajaran dan merumuskan tujuan, merencanakan pengorganisasikan materi, merencanakan langkah-langkah pembelajaran, memilih sumber dan media pembelajaran, dan merencanakan evaluasi pembelajaran.

2. Pelaksanaan Pembelajaran

Pada tahap pelaksanaan siklus 1, pertemuan pertama dilaksanakan hari Selasa, 9 Mei 2017 pukul 10.40 sampai 12.00 dengan alokasi waktu 2 x 40 menit. Selanjutnya pertemuan kedua dilaksanakan pada hari Rabu, 10 Mei 2017 pukul 12.30 sampai dengan 13.50 dengan alokasi waktu $2 \mathrm{x}$ 40 menit.

\section{Pengamatan (Observing)}

1. Pengamatan Terhadap Kemampuan Guru Merencanakan

Pembelajaran Siklus II

Sebagian besar aspek yang diamati dalam perencanaan pelaksanaan pembelajaran yang dilakukan sudah mencapai kriteria baik karena dari 16 aspek yang dinilai pada kemampuan guru merencanakan pembelajaran keterampilan membaca ekstensif menggunakan model pembelajaran reciprocal teaching terdapat 3 aspek kriteria sangat baik $(18,75 \%), 12$ aspek kriteria baik (75\%), 1 aspek kriteria cukup baik $(6,25 \%)$, dan 0 aspek kriteria kurang baik $(0 \%)$. Persentasinya $78,12 \%$ (baik).

2. Pengamatan terhadap Kemampuan Guru dalam melaksanakan Pembelajaran Siklus II

Sebagian besar aspek yang dinilai dalam pelaksanaan pembelajaran yang dilakukan sudah mencapai kriteria baik karena dari 30 aspek yang dinilai pada kemampuan guru melaksanakan pembelajaran keterampilan membaca ekstensif menggunakan model pembelajaran reciprocal teaching terdapat 13 aspek kriteria sangat baik (46,42\%), 14 aspek kriteria baik (50\%), 1 aspek kriteria cukup baik (3,57\%), dan 0 aspek kriteria kurang baik (0\%). Persentasinya 85,71\% (baik).

3. Pengamatan Terhadap Sikap Siswa dalam Pembelajaran Membaca Ekstensif Menggunakan Model Reciprocal Teaching 
Hasil pengamatan peneliti terhadap sikap dalam pembelajaran model problem based reciprocal teaching

a) Aspek mendengarkan penjelasan guru dengan skor 4 sebanyak 17 siswa $(60,71 \%)$, siswa dengan skor 3 sebanyak 9 siswa $(32,14 \%)$, siswa dengan skor 2 sebanyak 2 siswa $(7,14 \%)$, siswa dengan skor 1 sebanyak 0 siswa $(0 \%)$.

b) Aspek kerjasama skor 4 sebanyak 15 siswa $(53,57 \%)$, siswa yang mendapat skor 3 sebanyak 10 siswa $(35,71 \%)$ siswa dengan skor 2 sebanyak 3 siswa $(10,71 \%)$, siswa dengan skor 1 sebanyak 0 siswa $(0 \%)$.

c) Aspek tanggung jawab skor 4 sebanyak 6 siswa $(21,42 \%)$, siswa dengan skor 3 sebanyak 16 siswa $(57,14 \%)$, siswa dengan skor 2 sebanyak 6 siswa $(21,41 \%)$, siswa dengan skor 1 sebanyak 0 siswa $(0 \%)$.

d) Aspek disiplin skor 4 sebanyak 6 siswa $(21,42 \%)$, siswa dengan skor 3 sebanyak 20 siswa $(71,42 \%)$, siswa dengan skor 2 sebanyak 2 siswa $(7,14 \%)$, siswa dengan skor 1 sebanyak 0 siswa $(0 \%)$.

e) Aspek menghargai skor 4 sebanyak 12 siswa (42,85\%), siswa dengan skor 3 sebanyak 15 siswa $(53,57 \%)$, siswa dengan skor 2 sebanyak 1 siswa $(3,53 \%)$, siswa dengan skor 1 sebanyak 0 siswa $(0 \%)$.

\section{Hasil Pembelajaran Siswa dalam Membaca Ekstensif} Menggunakan Model Reciprocal Teaching Siklus II

Hasil keterampilan membaca ekstensif siswa menggunakan model pembelajaran reciprocal teaching pada siklus 1 sudah cukup baik dengan nilai tertinggi yaitu dengan nilai 90 dan nilai terendah yaitu 50. Nilai rata-rata kelas yang diperoleh pada siklus 2 mencapai 76,03 dan nilai persentase ketuntasan mencapai $85,71 \%$. Hal tersebut artinya sudah memenuhi standar kriteria ketuntasan tindakan yang ditentukan peneliti yaitu $70 \%$. Dengan demikian secara keseluruhan pada siklus 2 dalam mengikuti kegiatan pembelajaran keterampilan membaca ekstensif menggunakan model pembelajaran reciprocal teaching telah berhasil dan mengalami peningkatan.

\section{Refleksi (Reflection)}

1. Refeksi Terhadap Perencanaan

Dalam rencana pelaksanaan pembelajaran (RPP), sebagian besar aspek yang dinilai sudah mencapai kategori baik namun masih ada hal-hal yang perlu diperbaiki yaitu dalam hal menentukan alokasi waktu. Guru seharusnya dalam membagi waktu harus disesuaikan dengan banyaknya materi yang akan disampaikan, sehingga jika materi yang disampaikan banyak maka pembagiannya harus tepat.

2. Refleksi Terhadap Pelaksanaan

Refleksi terhadap pelaksanaan pembelajaran yang dilakukan oleh guru sebagian besar aspek yang dinilai sudah mencapai kategori baik namum masih ada hal-hal yang harus diperbaiki yaitu memeriksa kesiapan siswa, ruang, alat pembelajaran, dan media pembelajaran. Sebelum melakukan pembelajaran guru tidak memeriksa terlebih dahulu apa-apa saja yang diperlukan dalam proses pembelajaran. Seharusnya guru sebelum memulai pembelajaran guru terlebih dahulu mengecek kesiapan siswa.

\section{PEMBAHASAN}

Setelah melakukan dua siklus penelitian pada aspek keterampilan membaca terutama keterampilan membaca ekstensif menggunakan model pembelajaran reciprocal teaching pada siswa kelas VIII D MTs Negeri Singkawang Tahun Ajaran 2016/2017 yang dilakukan oleh peneliti dan guru bahasa Indonesia Shofy damayanti, S. Pd., diperoleh hasil sebgai berikut.

1. Kemampuan Guru Merencanakan Proses Pembelajaran Keterampilan Menulis Membaca Ekstensif Menggunakan Model Pembelajaran Reciprocal Teaching Siklus 1 dan Siklus 2

Tabel 1

Peningkatan Kemampuan Guru Merencanakan Proses Pembelajaran

\begin{tabular}{cccc}
\hline Keterangan & Siklus 1 & Siklus 2 & Peningkatan \\
\hline APKG 1 & $60,93 \%$ & $78,12 \%$ & $17,19 \%$ \\
\hline
\end{tabular}

2. Kemampuan Guru Melaksanakan Proses Pembelajaran Keterampilan Membaca Ekstensif Menggunakan Model Pembelajaran Reciprocal Teaching Siklus 1 dan Siklus 2

Tabel 2

Peningkatan Kemampuan Guru Melaksanakan Proses Pembelajaran

\begin{tabular}{lccc}
\hline Keterangan & Siklus 1 & Siklus 2 & Peningkatan \\
\hline APKG 2 & $68,75 \%$ & $85,71 \%$ & $16,96 \%$ \\
\hline
\end{tabular}

3. Ketuntasan Keterampilan Membaca Ekstensif Menggunakan Model Pembelajaran Reciprocal Teaching Siklus 1 dan 2

Tabel 3

Ketuntasan Keterampilan Membaca Ekstensif Menggunakan Model Pembelajaran Reciprocal Teaching Siklus 1 dan Siklus 2

\begin{tabular}{cccccc}
\hline Ket & Jlh Siswa & Nilai & Rata-rata & $\begin{array}{c}\text { Ketuntasan } \\
\text { Belajar }\end{array}$ \\
\hline Siklus 1 & 28 & 16 & 12 & $66,53 \%$ & $57,14 \%$ \\
Siklus 2 & 28 & 23 & 5 & $76,03 \%$ & $85,71 \%$ \\
\end{tabular}

\section{SIMPULAN DAN SARAN}

SIMPULAN

Berdasarkan analisis data dan hasil penelitian yang dilakukan di kelas VIII D MTs Negeri Singkawang berkaitan dengan kemampuan siswa dalam keterampilan membaca ekstensif menggunakan model pembelajaran reciprocal teaching maka dapat disimpulkan hal-hal sebagai berikut.

1. Perencanaan pembelajaran membaca ekstensif menggunakan model pembelajaran reciprocal teaching direncanakan pada dua siklus. Perencanaan pada siklus 1 masuk dalam kategori cukup baik dengan presentase $60,93 \%$ dan perencanaan pembelajaran siklus II masuk 
dalam kategori baik dengan presentase 78,12. Dalam hal ini perencanaan pembelajaran mengalami peningkatan sebanyak $17,19 \%$.

2. Pelaksanaan pembelajaran membaca ekstensif menggunakan model pembelajaran reciprocal teaching sangat membantu siswa dalam mengikuti proses pembelajaran yang tidak secara langsung dapat menumbuhkan minat siswa dalam proses belajar mengajar. Hal ini dapat dibuktikan dari adanya sebuah peningkatan yang terjadi pada saat mengikikuti proses pembelajaran menggunakan model pembelajaran reciprocal teaching pada siklus I mencapai $68,75 \%$ dan pada siklus II mencapai $85,71 \%$. Dalam hal ini pelaksanaan pembelajaran mengalami peningkatan sebanyak $16,96 \%$.

3. Hasil pembelajaran membaca ekstensif menggunakan model reciprocal teachig mengalami peningkatan pada setiap siklusnya. Hal ini dapat dibuktikan pada persentase nilai rata-rata hasil belajar siswa menggunakan model reciprocal teaching. Pada siklus 1 nilai rata-rata siswa mencapai $66,53 \%$ dengan kategori cukup baik, pada siklus II mencapai 76,03\% dengan katagori baik. Berdasarkan persentase yang diperoleh terlihat mengalami peningkatan sebanyak $17,93 \%$.

\section{SARAN}

Berdasarkan kesimpulan hasil tindakan, peneliti menyampaikan saran sebagai berikut.

1. Pendidik hendaknya selalu berusaha meningkatkan kinerjanya dalam proses pembelajaran seperti memperbaiki sebuah perencanaan pembelajaran, pelaksanaan pembelajaran serta metode-metode yang digunakan dalam proses pembelajaran, sehingga tujuan pembelajaran dapat tercapai dengan baik yang dibuktikan peningkatan hasil pembelajaran.

2. Peningkatan pembelajaran khususnya membaca ekstensif dalam mata pelajaran bahasa Indonesia hendaknya harus menggunakan model yang sesuai, satu di antaranya adalah model reciprocal teaching yang dapat membantu dalam proses pembelajaran. Ketika menggunakan model ini guru diharapkan terlebih dahulu menyusun rencana pembelajaran reciprocal teaching, langkah-langkah pembelajaran reciprocal teaching dan pelaksanaan model reciprocal teaching.

3. Dalam proses pembelajaran membaca ekstensif menggunakan model pembelajaran reciprocal teaching diharapkan siswa saling bekerja sama, sehingga proses pembelajaran menggunakan model reciprocal teaching dapat terlaksanana dengan baik, serta meningkatkan hasil belajar siswa.

\section{DAFTAR PUSTAKA}

Arikunto, Suharsimi. (2010). Penelitian Tindakan Kelas Jakarta: Bumi Aksara.

Arikunto, Suharsimi. (2015). Penelitian Tindakan Kelas Jakarta: Bumi Aksara.
Dalman. (2013). Keterampilan Membaca. Jakarta: Raja Grafindo Presada.

Moleong, Lexy J. (2014). Metode Penelitian Kualitatif. Bandung: Remaja Rosdakarya.

Nurgiyantoro, Burhan. (2010). Penilaian Pembelajaran Bahasa. Yogyakarta: Anggota IKAPI.

Slamet, St. Y. dan Saddhono Kundharu. (2012). Meningkatkan Keterampilan Berbahasa Indonesia. Bandung: Karya Putra Darwati.

Shoimin, Aris. (2016). 68 Model Pembelajaran Inovatif dalam Kurikulum 2013. Jogyakarta: Ar-Ruzz Media.

Sugiyono. (2016). Metode Penelitian Pendidikan. Bandung: Alfabeta.

Tarigan, Henry Guntur. (2008). Membaca Sebagai Suatu Keterampilan Berbahasa. Bandung: Angkasa.

Tritanto. (2014). Mendesain Model Pembelajaran Inovatif, Progresif, dan Kontekstual. Jakarta: Kencana. 